University of Nebraska - Lincoln

DigitalCommons@University of Nebraska - Lincoln

\title{
Storm Event and Continuous Hydrologic Modeling for Comprehensive and Efficient Watershed Simulations
}

\author{
Deva K. Borah \\ Woolpert Inc. \\ Jeffrey G. Arnold \\ USDA-ARS Grassland Soil and Water Research Laboratory, jeff.arnold@ars.usda.gov \\ Maitreyee Bara \\ Borah Hydro-Environmental Modeling \\ Edward C. Krug \\ IDNR \& UIUC \\ Xin-Zhong Liang \\ Center for Atmospheric Science
}

Follow this and additional works at: https://digitalcommons.unl.edu/usdaarsfacpub

Part of the Agricultural Science Commons

Borah, Deva K.; Arnold, Jeffrey G.; Bara, Maitreyee; Krug, Edward C.; and Liang, Xin-Zhong, "Storm Event and Continuous Hydrologic Modeling for Comprehensive and Efficient Watershed Simulations" (2007). Publications from USDA-ARS / UNL Faculty. 459.

https://digitalcommons.unl.edu/usdaarsfacpub/459

This Article is brought to you for free and open access by the U.S. Department of Agriculture: Agricultural Research Service, Lincoln, Nebraska at DigitalCommons@University of Nebraska - Lincoln. It has been accepted for inclusion in Publications from USDA-ARS / UNL Faculty by an authorized administrator of DigitalCommons@University of Nebraska - Lincoln. 


\title{
Storm Event and Continuous Hydrologic Modeling for Comprehensive and Efficient Watershed Simulations
}

\author{
Deva K. Borah, M.ASCE ${ }^{1}$; Jeffrey G. Arnold²; Maitreyee Bera ${ }^{3}$; Edward C. Krug ${ }^{4}$; and Xin-Zhong Liang ${ }^{5}$
}

\begin{abstract}
Based on recent reviews of 11 physically based watershed models, the long-term continuous model soil and water assessment tool (SWAT) and the storm event dynamic watershed simulation model (DWSM) were selected to examine their hydrologic formulations, calibrate, and validate them on the $620 \mathrm{~km}^{2}$ watershed of the upper Little Wabash River at Effingham, Ill., and examine their compatibility and benefits of combining them into a more comprehensive and efficient model. Calibration and validation of the SWAT by comparing monthly simulated and observed flows and adjusting the model-assigned resulted in coefficients of determination and Nash-Sutcliffe coefficients for individual years and cumulatively for the calibration period (1995-1999) and for the entire simulation period (1995-2002) mostly above or near 0.50 with an exception of 0.05 and -0.27 , respectively, in 2001 , relatively a dry year. Visual comparisons of the hydrographs showed SWAT's weakness in predicting monthly peak flows (mostly underpredictions.) Therefore, SWAT needs enhancements in storm event simulations for improving its high and peak flow predictions. Calibration of DWSM was not necessary; its three physically based parameters were taken from SWAT. Validation of DWSM on three intense storms in May 1995, March 1995, and May 2002 resulted 1, -29 , and $16 \%$ errors in peak flows and $0,-11$, and $0 \%$ errors in times to peak flows, respectively. Comparisons of DWSM's 15-min flow hydrographs with SWAT's daily flow hydrographs along with the 15-min and daily observed flow hydrographs during the above three storms confirmed that DWSM predicted more accurate high and peak flows and precise arrival times than SWAT. DWSM's robust routing scheme using analytical and approximate shock-fitting solutions of the kinematic wave equations was responsible for the better predictions, the addition of which along with its unique combination with the popular runoff curve number method for rainfall excess computation to SWAT would be a significant enhancement. Parameters and data of both the models are interchangeable and, therefore, are compatible and their combination will result in a more comprehensive and efficient model.
\end{abstract}

DOI: 10.1061/(ASCE)1084-0699(2007)12:6(605)

CE Database subject headings: Flood routing; Hydrologic models; Kinematic wave theory; Rainfall; Runoff; Watershed management; Storms.

\section{Introduction}

Watershed models that simplify and simulate complex natural processes are useful analysis tools for understanding and finding environmentally sensitive solutions to natural and manmade changes and problems within a watershed. Numerous watershed-

\footnotetext{
${ }^{1}$ Senior Project Manager, Woolpert Inc., 415 Port Centre Parkway, Suite 101, Portsmouth, VA 23704-4924 (corresponding author). E-mail: deva.boral@woolpert.com

${ }^{2}$ Agricultural Engineer and Research Hydraulic Engineer, USDA-ARS Grassland Soil and Water Research Laboratory, 808 East Blackland Rd., Temple, TX 76502. E-mail: jgarnold@spa.ars.usda.gov

${ }^{3}$ Senior Modeler, Borah Hydro-Environmental Modeling, 2812 Valley Brook Drive, Champaign, IL 61822-7621. E-mail: maitreyeebera@ yahoo.com

${ }^{4}$ Biogeochemist, Office of the Chief, Illinois State Water Survey, IDNR \& UIUC, 2204 Griffith Dr., Champaign, IL 61820-7495. E-mail: krug@sws.uiuc.edu

${ }^{5}$ Professional Scientist, Center for Atmospheric Science, Illinois State Water Survey, IDNR and UIUC, 2204 Griffith Dr., Champaign, IL 61820-7495. E-mail: xliang@uiuc.edu

Note. Discussion open until April 1, 2008. Separate discussions must be submitted for individual papers. To extend the closing date by one month, a written request must be filed with the ASCE Managing Editor. The manuscript for this paper was submitted for review and possible publication on January 24, 2006; approved on November 27, 2006. This paper is part of the Journal of Hydrologic Engineering, Vol. 12, No. 6, November 1, 2007. CASCE, ISSN 1084-0699/2007/6-605-616/\$25.00.
}

scale models are available today, mostly simulating hydrologic with or without nonpoint-source pollution processes, and a fewhaving economic components as well (Singh 1995; Singh and Frevert 2002a,b, 2006). The models have varying capabilities, sophistications, strengths, and weaknesses. Therefore, selection of the most suitable model for a specific application can be daunting. Simple models are generally more efficient (robust) than comprehensive and sophisticated models, however their applications are limited to simplified cases. Comprehensive and sophisticated, as well as robust, models are needed for practicing engineers, scientists, and managers to address and solve today's complex water resources and sensitive environmental issues and problems, such as water supply (e.g., Borah et al. 2006a) and total maximum daily load (e.g., Borah et al. 2006b), and can only be achieved through continued research. Physically based watershed-scale models are more useful to the end users because of their suitability to predict impacts of future natural (e.g., climate) or manmade (e.g., land use or management practice) changes and, therefore, this study focuses on physically based and watershed-scale models only.

A detailed review and comparisons of 11 physically based watershed-scale hydrologic and nonpoint-source pollution models were given in Borah and Bera (2003). The models reviewed were: The agricultural nonpoint-source pollution model (AGNPS) (Young et al. 1987), annualized AGNPS (AnnAGNPS) (Bingner and Theurer, unpublished report, USDA-ARS National Sedimentation Laboratory, 2001), areal nonpoint-source watershed envi- 
ronment response simulation (ANSWERS) (Beasley et al. 1980), ANSWERS-continuous (Bouraoui et al. 2002), CASCade of planes in 2-dimensions (CASC2D) (Ogden and Julien 2002), dynamic watershed simulation model (DWSM) (Borah et al. 2002), hydrologic simulation program-Fortran (HSPF) (Bicknell et al. 1993), kinematic runoff and erosion model (KINEROS) (Woolhiser et al. 1990), the European hydrological system model (MIKE SHE) (Refsgaard and Storm 1995), precipitation-runoff modeling system (PRMS) (Leavesley et al. 1983), and soil and water assessment tool (SWAT) (Arnold et al. 1998).

Borah and Bera's (2003) review found that AGNPS, AnnAGNPS, DWSM, HSPF, MIKE SHE, and SWAT were more fully developed (comprehensive) than the other models having all three major components: hydrology, sediment, and chemical. Among these models, AnnAGNPS, HSPF, and SWAT are continuous simulation models useful for analyzing mainly long-term impacts of hydrological changes and watershed management practices, AGNPS and DWSM are storm-event simulation models useful for analyzing watershed responses from severe or extreme storm events and evaluating watershed management practices, and MIKE SHE has both the long-term continuous and stormevent simulation capabilities. AGNPS is a simple and lumped model. Although AnnAGNPS is similar to SWAT, it is not as comprehensive as SWAT. MIKE SHE, the most physically based model, is data and computationally intensive for efficient applications. Therefore among the physically based long-term continuous models reviewed, HSPF and SWAT were the most comprehensive and efficient continuous watershed models; SWAT for agricultural watersheds and HSPF for mixed agricultural and urban watersheds. Among the physically based storm event models reviewed, DWSM was the most comprehensive and efficient storm-event watershed model.

Reviews of applications of these three models (Borah and Bera 2004) indicated that HSPF and SWAT were reliable for yearly and monthly (average or yield) predictions, except for the months having severe hydrologic conditions (storms). Daily predictions from HSPF and SWAT were less reliable, especially for the days having intense storms. Therefore, HSPF and SWAT are not suitable for analyzing severe storm events. On the other hand, DWSM being a storm event model, performed well in simulating storm events, including intense storms. In two recent comparative investigations of HSPF and SWAT, Van Liew et al. (2003) and Saleh and Du (2004) found that SWAT exhibited more robustness and proved to be a better predictor than HSPF.

These comparative studies suggested that research must continue to combine strengths of different models for developing more comprehensive and efficient models, an idea shared by others, such as Perrin et al. (2001). Therefore, based on the above reviews, the continuous SWAT, a widely used model at the present time, and the storm event DWSM were selected in this study to examine and test their compatibility and benefit of combining them into a more comprehensive and efficient physically based watershed simulation model.

Both the models were applied to the $8,400 \mathrm{~km}^{2}$ Little Wabash River watershed in Illinois having predominantly agricultural land uses (Borah et al. 2006a). Using multiyear period (1995-2002) of daily precipitation and air temperature data at 14 stations and daily flow and approximately once a month water quality data at four gaging stations and manually adjusting the model-suggested parameter values, the continuous SWAT was calibrated and validated. Using storm event rainfall and flow data (15 min intervals) from three relatively intense storms in May 1995, March 1995, and May 2002, and values of three parameters (curve number,
Manning's roughness coefficient, and saturated hydraulic conductivity) calibrated and validated in SWAT, the DWSM's storm event hydrology model was validated for the upper portion of the watershed draining $620 \mathrm{~km}^{2}$ to Effingham. In this paper, the hydrologic formulations of both the models and their simulation results at Effingham are presented and compatibility of the two models and benefits of combining them into one are discussed.

\section{SWAT-Continuous Hydrologic Model}

SWAT, developed at the United States Department of Agriculture (USDA) Agricultural Research Service (ARS) Grassland, Soil, and Water Research Laboratory in Temple, Tex. (Arnold et al. 1998; Neitsch et al. 2002), is a well-developed model with geographic information system (GIS) and graphical user interfaces, and is a part of the United States Environmental Protection Agency's (USEPA) better assessment science integrating point and nonpoint sources (BASINS) modeling system (USEPA 2001; DiLuzio et al. 2002). It was developed to assist water resources managers in predicting and assessing the impact of management on water, sediment, and agricultural chemical yields in large ungaged watersheds or river basins. The model was intended for long term yield predictions and not for detailed single-event flood routing.

SWAT and its routines were presented by its developers in various publications; more recently in Neitsch et al. (2002) with overwhelming details and backgrounds. A complete streamlined presentation is necessary for a clear understanding of its scientific basis and, therefore, such a presentation of its hydrologic formulations is attempted here with consistent mathematical symbols.

The watershed is divided into a number of subwatersheds or subbasins, which are grouped based on climate, hydrologic response units (HRU), ponds, groundwater, and main channels. HRUs are lumped land areas within the subbasin comprised of unique land cover, soil, and management combinations. The daily water budget in each HRU is computed as

$$
\mathrm{SW}_{t}=\mathrm{SW}_{0}+\sum_{i=1}^{t}\left(R_{i}-Q_{\mathrm{surf}, i}-Q_{\mathrm{et}, i}-Q_{\mathrm{perc}, i}-Q_{\mathrm{gwrf}, i}\right)
$$

where $\mathrm{SW}_{t}=$ final soil water content $(\mathrm{mm}) ; t=$ time (days); $\mathrm{SW}_{0}=$ initial soil water content $(\mathrm{mm}) ; R_{i}=$ precipitation on day $i$ (mm); $Q_{\text {surf }, i}=$ surface runoff on day $i(\mathrm{~mm}) ; Q_{\mathrm{et}, i}=$ evapotranspiration $(\mathrm{ET})$ on day $i(\mathrm{~mm}) ; Q_{\mathrm{perc}, i}=$ percolation on day $i(\mathrm{~mm})$; and $Q_{\mathrm{gwrf}, i}=$ groundwater return flow, or base flow, on day $i(\mathrm{~mm})$.

\section{Surface Runoff}

Daily surface runoff is computed from daily rainfall using the Soil Conservation Service's (presently called Natural Resources Conservation Service) (SCS 1972) runoff curve number procedure, where the runoff volume is expressed as

$$
Q_{\text {surf }, i}=\frac{\left(R_{i}-0.2 S_{r}\right)^{2}}{R_{i}+0.8 S_{r}}
$$

where $S_{r}=$ retention parameter $(\mathrm{mm})$.

The retention parameter $S_{r}$ depends upon soil cover complexes, including soil, land use, management, and initial soil moisture (antecedent conditions), and is expressed as 


$$
S_{r}=\frac{25,400}{\mathrm{CN}}-254
$$

where $\mathrm{CN}=$ runoff curve number.

The CN indicates runoff potential and its values are given by SCS $(1972,1986)$ for different soil-cover complexes, including three antecedent moisture conditions: $I=$ dry (wilting point); $\mathrm{II}=$ average moisture; and III=wet (field capacity). The practical $\mathrm{CN}$ values given by SCS range from 30 to 95 , however, the potential values may range from 1 to 100 . Using an average moisture condition curve number (CN2) for the given soil-cover complex of a HRU, SWAT uses procedures that revise its value for HRU slopes other than 5\% and continuously updates $S_{r}$ values, as well as $\mathrm{CN}$ values, daily, based on $\mathrm{SW}_{t}$ values. Without detailed soil-cover complex information, the $\mathrm{CN} 2$ may be calibrated by matching simulated surface runoff with observed values, as was done in the present study.

The amount of surface runoff from a HRU or subbasin reaching the main channel is computed as

$$
Q_{\mathrm{ch}, i}=\left(Q_{\mathrm{surf}, i}+Q_{\mathrm{stor}, i-1}\right) \cdot\left[1-e^{\left(- \text {surlag }_{\mathrm{conc}}\right)}\right]
$$

where $Q_{\mathrm{ch}, i}=$ amount of surface runoff discharged into the main channel on day $i(\mathrm{~mm}) ; Q_{\text {stor }, i-1}=$ amount of surface runoff stored or lagged from day $i-1(\mathrm{~mm})$ and is equal to $\left(Q_{\mathrm{stor}, i-2}+Q_{\mathrm{sur}, i-1}-Q_{\mathrm{ch}, i-1}\right)$; surlag= surface runoff lag coefficient; and $t_{c o n c}=$ time of concentration for the subbasin (h).

\section{Evapotranspiration}

Evapotranspiration (ET) includes all processes by which water at the earth's surface is converted to water vapor: evaporation from the plant canopy, transpiration, sublimation, and evaporation from the soil. SWAT estimates ET $\left(Q_{\mathrm{et}, i}\right)$ from potential evapotranspiration (PET), which is calculated using three alternative methods: Hargreaves (Hargreaves and Samani 1985), Priestley-Taylor (Priestley and Taylor 1972), and Penman-Monteith (Monteith 1965). The Priestley-Taylor method is used in this study.

\section{Percolation}

Percolation is calculated for each soil layer in the profile when water content exceeds field capacity. The amount of water that moves from one layer to the underlying layer is calculated using storage routing methodology and is expressed as

$$
Q_{\text {perc }, i}=\mathrm{SW}_{\text {excess }, i} \cdot\left[1-e^{\left(-\Delta t / \mathrm{TT}_{\mathrm{perc}}\right)}\right]
$$

where $\mathrm{SW}_{\text {excess }, i}=$ drainable volume of water in the soil layer on day $i(\mathrm{~mm}) ; \Delta t=$ time interval $(24 \mathrm{~h})$; and $\mathrm{TT}_{\text {perc }}=$ percolation travel time for the soil layer (h).

The percolation travel time for a soil layer is calculated as

$$
\mathrm{TT}_{\text {perc }}=\frac{\mathrm{SW}_{\text {sat }}-\mathrm{SW}_{\text {cap }}}{K_{\text {sat }}}
$$

where $\mathrm{SW}_{\text {sat }}=$ amount of water in the soil layer when completely saturated $(\mathrm{mm}) ; \mathrm{SW}_{\text {cap }}=$ water content of the soil layer at field capacity $(\mathrm{mm})$; and $K_{\text {sat }}=$ saturated hydraulic conductivity for the layer $(\mathrm{mm} / \mathrm{h})$.

\section{Lateral Subsurface Flow}

SWAT calculates lateral subsurface flow in the soil layer simultaneously with percolation using a kinematic storage model (Sloan et al. 1983), which is expressed as

$$
Q_{\mathrm{lat}, i}=0.024 \cdot\left(\frac{2 \cdot \mathrm{SW}_{\mathrm{excess}, i} \cdot K_{\mathrm{sat}} \cdot \mathrm{slp}}{\phi_{d} \cdot L_{\mathrm{hill}}}\right)
$$

where $Q_{\text {lat }, i}=$ lateral subsurface flow in the soil layer (water discharged from the hillslope outlet) on day $i(\mathrm{~mm})$; slp=slope of the hillslope segment $(\mathrm{m} / \mathrm{m}) ; \varphi_{d}=$ drainable porosity of the soil layer $(\mathrm{mm} / \mathrm{mm})$, which is the difference between porosity of the layer on day $i$ and its porosity at field capacity; and $L_{\text {hill }}=$ hillslope length $(\mathrm{m})$.

Once lateral flow is calculated, the amount of lateral flow released to the main channel is calculated using a lag equation similar to Eq. (4).

\section{Tile Flow}

Tile drainage occurs when the soil water content exceeds field capacity. In the soil layer where the tile drains are installed, the amount of water entering the drain on a given day is calculated as

$$
Q_{\mathrm{tile}, i}=\left(\mathrm{SW}_{t}-\mathrm{SW}_{\mathrm{cap}}\right) \cdot\left[1-e^{\left(-24 / t_{\mathrm{drain}}\right)}\right]
$$

where $Q_{\text {tile }, i}=$ amount of water removed from the layer by tile on day $i(\mathrm{~mm})$; and $t_{\text {drain }}=$ time required to drain the soil to field capacity (h).

Water entering tiles is treated as lateral flow, which lags while discharging into the main channel and is treated similar to Eq. (4).

\section{Groundwater Flow}

Groundwater return flow is derived from a water balance equation for the shallow aquifer, which is

$$
\mathrm{aq}_{\mathrm{sh}, i}=\mathrm{aq}_{\mathrm{sh}, i-1}+\mathrm{Q}_{\mathrm{rchrg}, i}-\mathrm{Q}_{\mathrm{gwrf}, i}-\mathrm{Q}_{\mathrm{revap}, i}-\mathrm{Q}_{\text {deep }, i}-\mathrm{Q}_{\mathrm{pump}, i}
$$

where $\mathrm{aq}_{\mathrm{sh}, i}=$ amount of water stored in the shallow aquifer on day $i(\mathrm{~mm}) ; \mathrm{Q}_{\mathrm{rchrg}, i}=$ amount of recharge entering the aquifer on day $i(\mathrm{~mm}) ; Q_{\text {revap }, i}=$ amount of water moving into the soil zone in response to water deficiencies on day $i(\mathrm{~mm}) ; Q_{\text {deep }, i}=$ amount of water percolating from shallow aquifer into the deep aquifer on day $i(\mathrm{~mm})$; and $Q_{\text {pump }, i}=$ amount of water removed from the shallow aquifer by pumping on day $i(\mathrm{~mm})$.

The recharge to the aquifer on a given day is calculated as

$$
Q_{\mathrm{rchrg}, i}=Q_{\mathrm{perc}, i} \cdot\left[1-e^{\left(-1 / \delta_{g w}\right)}\right]+Q_{\mathrm{rchrg}, i-1} \cdot e^{\left(-1 / \delta_{g w}\right)}
$$

where $\delta_{\mathrm{gw}}=$ delay time or drainage time of the overlying geologic formations (day).

Groundwater return or base flow is computed as

$$
Q_{\mathrm{gwr}, i}=Q_{\mathrm{rchrg}, i} \cdot\left[1-e^{-\alpha_{\mathrm{gw}} \Delta r}\right]+Q_{\mathrm{gwrf}, i-1} \cdot e^{-\alpha_{\mathrm{gw}} \Delta t}
$$

where $\alpha_{\mathrm{gw}}=$ groundwater or base flow recession constant; and $\Delta t=$ time step (1 day).

\section{Channel Flow Routing}

All the water $\left(Q_{\mathrm{ch}, i}, Q_{\mathrm{lat}, i}, Q_{\mathrm{tile}, i}\right.$, and $\left.Q_{\mathrm{gwrf}, i}\right)$ reaching the main channels is routed through the channel network of the watershed using a variable storage coefficient method (Williams 1969) or the Muskinguni routing method (Linsley et al. 1958). SWAT accounts for transmission losses, which reduce runoff volume as water moves downstream through the channel network. 


\section{DWSM-Storm-Event Hydrologic Model}

Although DWSM was presented earlier in Borah et al. (2002; 2004), a brief parallel description of its hydrologic formulations is given here to show contrast of this storm event model with the SWAT continuous model along with their interchangeable, compatible, or complementary features.

The watershed is divided into one-dimensional overland planes, channel segments, and reservoir units and can be processed from the SWAT input data. Each SWAT subwatershed is divided into two overland planes and one channel segment. An overland plane is represented as a rectangle, the width is equal to the adjacent (receiving) channel length, and the length is equal to the overland plane area divided by the width. Representative slope, soil, land cover, and roughness are based on physical measurements and observations, which can also be obtained from weighted averages of the respective variables from the SWAT HRUs present in an overland plane. A channel segment is represented with a straight channel having the same length as in the field and having a representative cross-sectional shape, slope, and roughness based on physical measurements and observations or from SWAT data. A reservoir unit is represented with a stagestorage-discharge relation (table) developed based on topographic data and discharge calculations using outlet measurements and established equations.

\section{Rainfall Excess and Infiltration}

The storm event DWSM computes rainfall excess rates on overland planes at small time intervals ( $\mathrm{min}$ ) using the SCS (1972) runoff curve number equations [Eqs. (2) and (3)], cumulative rainfall depths at each time step (total number of time intervals from beginning of simulation), and the following equation

$$
I_{e, i}=\frac{Q_{\text {surf }, i}-Q_{\text {surf }, i-1}}{\Delta t_{i}}
$$

where $i=$ time step: total number of time intervals from beginning of simulation [not day as in Eq. (2)]; $\Delta t_{i}=$ time interval between time steps $i-1$ and $i(\mathrm{~h}) ; I_{e, i}=$ rainfall excess rate during time interval $\Delta t_{i}(\mathrm{~mm} / \mathrm{h})$; and $Q_{\text {surf }, i}=$ accumulated rainfall excess at time step $i(\mathrm{~mm})$.

Eq. (12) is presented here for the first time in the form of a mathematical expression although the procedure was described earlier in Borah (1989). Accumulated rainfall excess $\left(Q_{\text {surf }, i}\right)$ is computed using Eq. (2), but replacing daily rainfall $\left(R_{i}\right)$ with cumulative rainfall depth at time step $i$. Assuming that evapotranspiration is negligible during a storm event, infiltration rates are computed by subtracting the rainfall excess rates $\left(I_{e, i}\right)$ from rainfall intensities (rates) during the corresponding time intervals. This rainfall excess computation procedure is much simpler than any other physically based procedure using interception and infiltration equations because of the single parameter, the runoff curve number $\mathrm{CN}$, which is proven to be useful for half a century. $\mathrm{CN}$ is assumed to be uniform in each of the overland planes and may be estimated based on physical characteristics of the soil-cover complex (SCS 1972, 1986), which includes antecedent moisture condition, or calibrated using flow measurements (e.g., Borah 1989; Borah et al. 2004). In this study, CN was taken from the average moisture condition $\mathrm{CN} 2$ values calibrated in SWAT, without any adjustment for daily soil moisture. Once DWSM is merged into SWAT, it will be able to use the daily updated value of $\mathrm{CN}$ from SWAT.

\section{Surface Water Routing in Overland Planes and Channel Segments}

The surface water routing algorithm for both overland planes and channel segments is based on kinematic wave approximations (Lighthill and Whitham 1955) of the Saint-Venant or shallow water wave equations governing unsteady free surface flows. The governing equations are, respectively, the continuity and the approximate momentum equations

$$
\begin{gathered}
\frac{\partial A}{\partial t}+\frac{\partial Q}{\partial x}=q \\
Q=\alpha A^{m}
\end{gathered}
$$

where $A=$ flow cross-sectional area $\left(\mathrm{m}^{2}\right) ; Q=$ flow rate of water discharge $\left(\mathrm{m}^{3} / \mathrm{s}\right) ; q=$ rate of lateral inflow per unit length $\left(\mathrm{m}^{3} / \mathrm{s} / \mathrm{m}\right) ; t=$ time $(\mathrm{s}) ; x=$ downslope position $(\mathrm{m}) ; \alpha=$ kinematic wave parameter; and $m=$ kinematic wave exponent.

Eqs. (13) and (14) are written for a channel, and are also used for overlands simply by substituting $A, Q$, and $q$ with flow depth $(\mathrm{m})$, rate of water discharge per unit width $\left(\mathrm{m}^{3} / \mathrm{s} / \mathrm{m}\right)$, and rate of rainfall excess $I_{e}(\mathrm{~m} / \mathrm{s})$, respectively. The kinematic wave parameter $\alpha$ and the exponent $m$ are assumed independent of time and piecewise uniform in space (constant within each overland plane or channel segment), and are expressed as

$$
\begin{gathered}
\alpha=\frac{S^{1 / 2}}{n a^{2 / 3}} \\
m=(5-2 b) / 3 \\
P=a A^{b}
\end{gathered}
$$

where $S=$ longitudinal bed slope $(\mathrm{m} / \mathrm{m}) ; n=$ Manning's roughness coefficient; $P=$ wetted perimeter $(\mathrm{m})$; and $a$ and $b=$ coefficient and exponent, respectively, in wetted perimeter versus flow area relation.

For overland planes, $a=1.0$ and $b=0.0$, where $P=1.0$ for unit width overland flow routing. For a channel segment, $a$ and $b$ are estimated from cross-sectional measurements. The lateral inflow $q$ is assumed piecewise uniform in space and piecewise constant in time (constant over a time interval). The Manning's roughness coefficient $(n)$ is assumed piecewise uniform; uniform in each of the overland planes and channel segments. In this study, $n$ is taken from its estimated values in SWAT.

The water routing scheme is based on analytical and approximate shock-fitting solutions of Eqs. (13) and (14) using the method of characteristics, as described in Borah et al. (1980), Borah (1989), or Borah et al. (2002). The scheme is robust because of the closed-form solutions and only one calibration parameter, the Manning's roughness coefficient $n$. It must be noted that the kinematic wave equations [Eqs. (13) and (14)] generate only one system of characteristics, which means that they cannot represent waves traveling upstream as in the case of backwater flow. Therefore, the water routing scheme is not applicable when backwater flows are present, generally from downstream control (e.g., dams and weirs), flooding, storm surge, or flood tide, which may occur and influence limited (small) flow lengths in an upland watershed, however, their overall influence may be quite negligible, especially during intense storms. Any error generated from the approximations of this robust scheme can be corrected or compensated for through adjustment (calibration) of the roughness factor (parameter) $n$. 


\section{Subsurface Flow Routing underneath Overland Planes}

The subsurface flow could be accelerated due to the presence of tile drains. In DWSM, the subsurface flow is computed using the kinematic storage equation [Eq. (7)] of Sloan et al. (1983), used in SWAT. Eq. (7) is slightly modified here for dimensional consistencies and expressed as

$$
q_{s}=K_{s} \sin \alpha \frac{2 V}{L\left(\theta_{s}-\theta_{d}\right)}
$$

where $q_{s}=$ subsurface flow per unit overland width $\left(\mathrm{m}^{3} / \mathrm{s} / \mathrm{m}\right)$; $K_{s}=$ lateral saturated hydraulic conductivity $(\mathrm{m} / \mathrm{s}) ; \alpha=$ angle of the impermeable bed (deg); $V=$ drainable volume of water stored in the saturated zone of a unit width of overland $\left(\mathrm{m}^{3} / \mathrm{m}\right) ; L=$ slope length $(\mathrm{m}) ; \theta_{s}=$ saturated water content $\left(\mathrm{m}^{3} / \mathrm{m}^{3}\right)$; and $\theta_{d}=$ field capacity $\left(\mathrm{m}^{3} / \mathrm{m}^{3}\right)$.

Eq. (18) is used with a modification to the $K_{s}$ term to represent the lateral subsurface and tile-drain contributions from the overland planes to the channel flows, including base flows. In the presence of a tile drainage system, the overall hydraulic conductivity increases, and as a result the subsurface flow contribution to the channels $\left(q_{s}\right)$ also increases. Therefore, the tile drainage system in the model is represented through modifying the saturated hydraulic conductivity $\left(K_{s}\right)$ to a combined hydraulic conductivity called the "effective lateral saturated hydraulic conductivity (ELSHC)." The ELSHC depends on porosity of the soil and the tile drainage system and may be different from field to field and overland to overland. In the model, ELSHC is assumed to be time independent and its value for each overland plane is estimated through calibration and validation using monitored flow data. In this study, values for ELSHC were taken from the $K_{s}$ values in SWAT, which may require adjustments or calibration in other applications. These values are provided in the SWAT's menu from the literature for different soil characteristics.

Conservation of subsurface water mass is maintained by continuously updating the water volume $(V)$ through solving the following spatially uniform and temporarily varying continuity equation

$$
f L-q_{s}=\frac{d V}{d t}
$$

where $f=$ rate of infiltration: difference between rainfall intensity and rainfall excess rate $I_{e}(\mathrm{~m} / \mathrm{s})$; and $t=$ time $(\mathrm{s})$.

In contrast to SWAT, DWSM simplifies and lumps lateral subsurface, tile, and groundwater flows into the subsurface flows needing estimation or calibration of the only parameter ELSHC, which is similar to $K_{s}$, a physically based parameter.

\section{Model Applications to Little Wabash River Watershed}

The 8,400-km² Little Wabash River Watershed (Fig. 1) in Illinois is the subject of an investigation for the Midwest Technology Assistance Center at the University of Illinois at UrbanaChampaign, in which, the watershed is modeled to evaluate (assess) water quantities and qualities at intakes of small drinking water supply systems within the watershed (Borah et al. 2006a). The watershed consists of two United States Geological Survey (USGS) eight-digit hydrologic cataloging unit (HUC) watersheds: watersheds of the main-stem Little Wabash River (HUC No. 05120114) and the Skillet Fork River (HUC No. 05120115). For Illinois, the Little Wabash River watershed has a relatively high density of public intrastate surface water supplies. There are seven small (population $<10,000$ ) Altamont, Clay City, Fairfield, Flora, Neoga, Olney, and Wayne City; and three large public surface water supply systems: Effingham $(18,065)$, Mattoon $(19,787)$, and the Rend Lake Intercity Water Systems $(110,778)$, serving communities in the watershed. All but the last system draw water from within the watershed.

The Little Wabash River is a principal tributary of the Wabash River; the latter is the largest source of nitrate-nitrogen $\left(\mathrm{NO}_{3}-\mathrm{N}\right)$ to the Ohio River (Goolsby et al. 1999). Virtually every major stream and river mile of the Little Wabash River watershed has impairment from sediment, nutrient enrichment, and other agricultural chemicals (IEPA 2004). All of the water supply sources have detectable levels of atrazine, a commonly used herbicide, but few exceed the maximum allowable concentration of $1 \mathrm{ppb}$ (USGS and IEPA 2003). The developmental history of the Little Wabash River watershed shows that watershed growth was retarded by the low level of water resources development (State Water Survey Staff 1948; Barker et al. 1967; United State (U.S.) Army Corps of Engineers 1979)-resulting in a very rural and sparsely populated agricultural watershed, the least developed major watershed in Illinois (IDNR 2001).

Rainfall data at 14 National Weather Service (NWS) stations in and around the watershed (Mattoon, Effingham, Mason, Newton, Louisville, Salem, Iuka, Flora, Clay City, Olney, Fairfield, Mt. Vernon, Wayne City, and Carmi) are available from the National Climatic Data Center or NCDC (2005). Daily rainfall data are available at all the stations, but $15-\mathrm{min}$ interval data are available at only a few of the stations (e.g., Effingham, Mason, Flora, and Carmi). Any missing data are filled with estimates from available observations at neighboring stations.

There are four active USGS gaging stations in the watershed having daily and 15-minute flow records: Little Wabash River at Effingham $\left(620 \mathrm{~km}^{2}\right)$, Clay City $\left(2,930 \mathrm{~km}^{2}\right)$, and Carmi $\left(8,000 \mathrm{~km}^{2}\right.$, near the watershed outlet); and Skillet Fork at Wayne City $\left(1,200 \mathrm{~km}^{2}\right)$ (Fig. 1). Daily and 15 -min flow records were obtained, respectively, from USGS (2005) and G. Johnson (personal communication, January 5, 2005, USGS, Urbana, Ill.). Flow records at only the Effingham station were used in this study.

\section{Application of SWAT Continuous Hydrologic Model}

The SWAT was applied to the Little Wabash River watershed. GIS data on topography, soil, and land use for the two USGS eight-digit watersheds in the Little Wabash River watershed were retrieved from links provided at the USEPA's (2007) BASINS database. These data were used to define watershed and subwatershed boundaries, compute their dimensions and representative slopes, and estimate various model parameters. The watershed was divided into 88 subwatersheds. The model groups these subwatersheds based on climate, HRUs, ponds, groundwaters, and main channels. HRUs are lumped land areas within the subbasin which are comprised of unique land cover, soil, and management combinations with uniform parameter values. Parameters are physically based, whose ranges of values are given by the model, and are manually adjusted within the given range during model calibration to best match the simulated runoff volumes with those observed. Daily precipitation and air temperature data at the 14 precipitation gages were obtained from the NCDC. Based on availability of data, a 5-year period (1995-1999) was chosen to calibrate the model and a 3-year period (2000-2002) was chosen to validate it. 


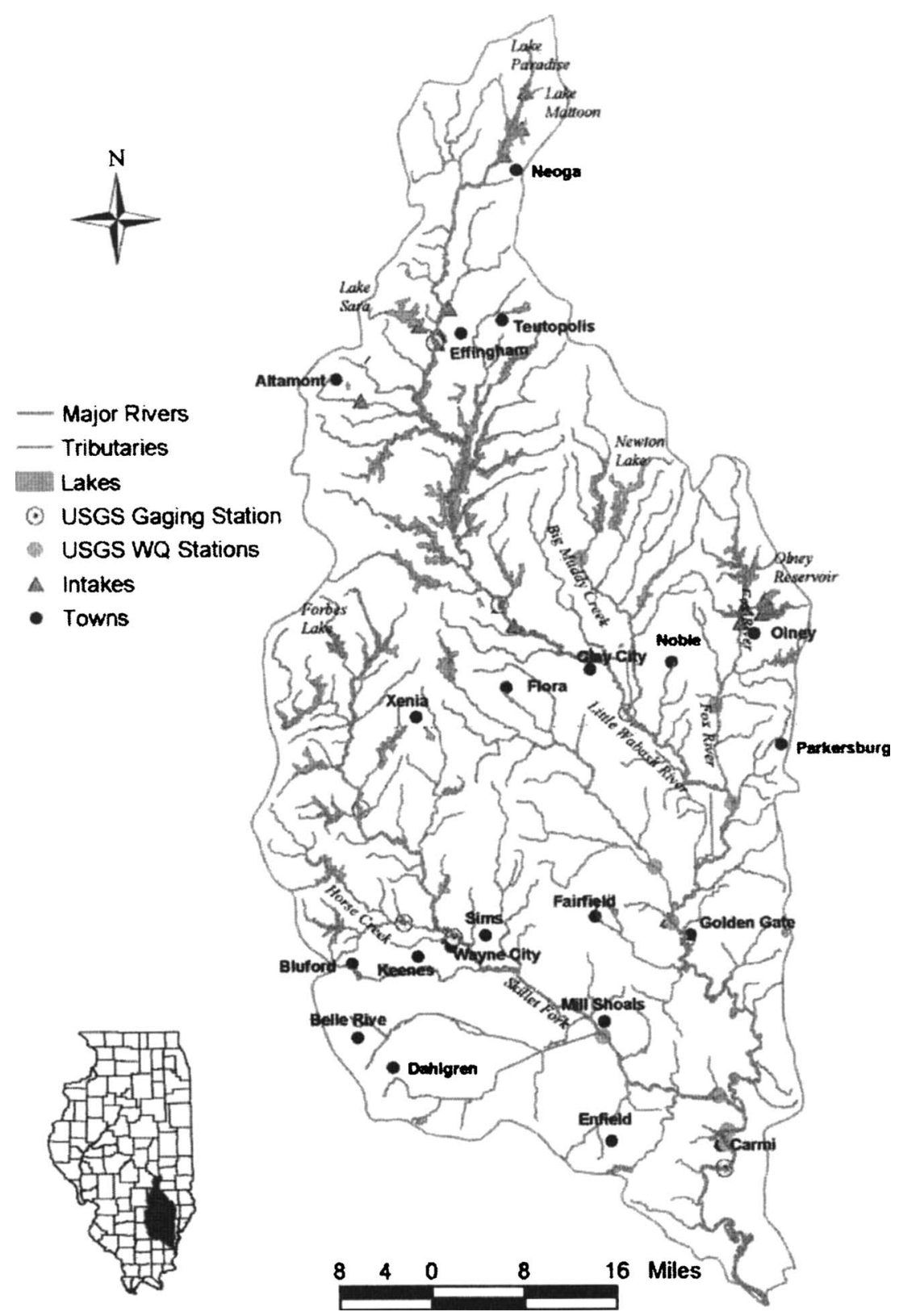

Fig. 1. Little Wabash River Watershed in Illinois $(1 \mathrm{mi}=1.609 \mathrm{~km})$

Calibration was conducted by comparing and best matching simulated monthly flows with observed monthly flows and adjusting nine parameters for the subwatersheds contributing to a gaging station, including: (1) SCS runoff curve number CN2 for average antecedent moisture (Condition II); (2) soil evaporation compensation factor ESCO; (3) plant uptake compensation factor EPCO; (4) threshold water level in shallow aquifer for base flow GWQMN; (5) threshold water level in shallow aquifer for reevaporation and/or deep percolation REVAPMN; (6) groundwater re-evaporation coefficient GW_REVAP; (7) groundwater delay GW_DELAY; (8) baseflow recession constant ALPHA_BF; and (9) deep aquifer percolation fraction RCHRG_DP. Once calibrated, parameters for upstream subwatersheds were kept the same while adjusting those on further downstream subwatersheds based on downstream flows.

Fig. 2 shows monthly (average) simulated and observed stream flows on the Little Wabash River at Effingham $\left(620 \mathrm{~km}^{2}\right)$ along with monthly average precipitations computed from two of the precipitation stations (Effingham and Mason) located in the vicinity of this upper watershed for both the calibration and validation periods (1995-2002). Fig. 3 shows coefficient of determination (COD) (or $r^{2}$ ) and Nash-Sutcliffe coefficient (NSC) (Nash and Sutcliffe 1970) values computed from the simulated and observed monthly flows for the individual years [Fig. 3(a)] and cumulatively at an increment of 1 year for the entire 1995-2002 simulation period [Fig. 3(b)] showing their values for the entire period as well for the 1995-1999 calibration period. Calibration during the first 5 years (1995-1999) resulted in the highest combined (cumulative) COD of 0.58 and NSC of 0.57 [Fig. 3(b)]; the latter being above the satisfactory performance value $(\mathrm{NSC}=0.36)$ used by others (e.g., Van Liew et al. 2003). The COD and NSC values for the individual calibration years ranged from 0.45 to 0.81 and 0.28 to 0.77 , respectively, mostly above or near 0.50 showing satisfactory performance.

The parameters were adjusted manually to get the highest pos- 


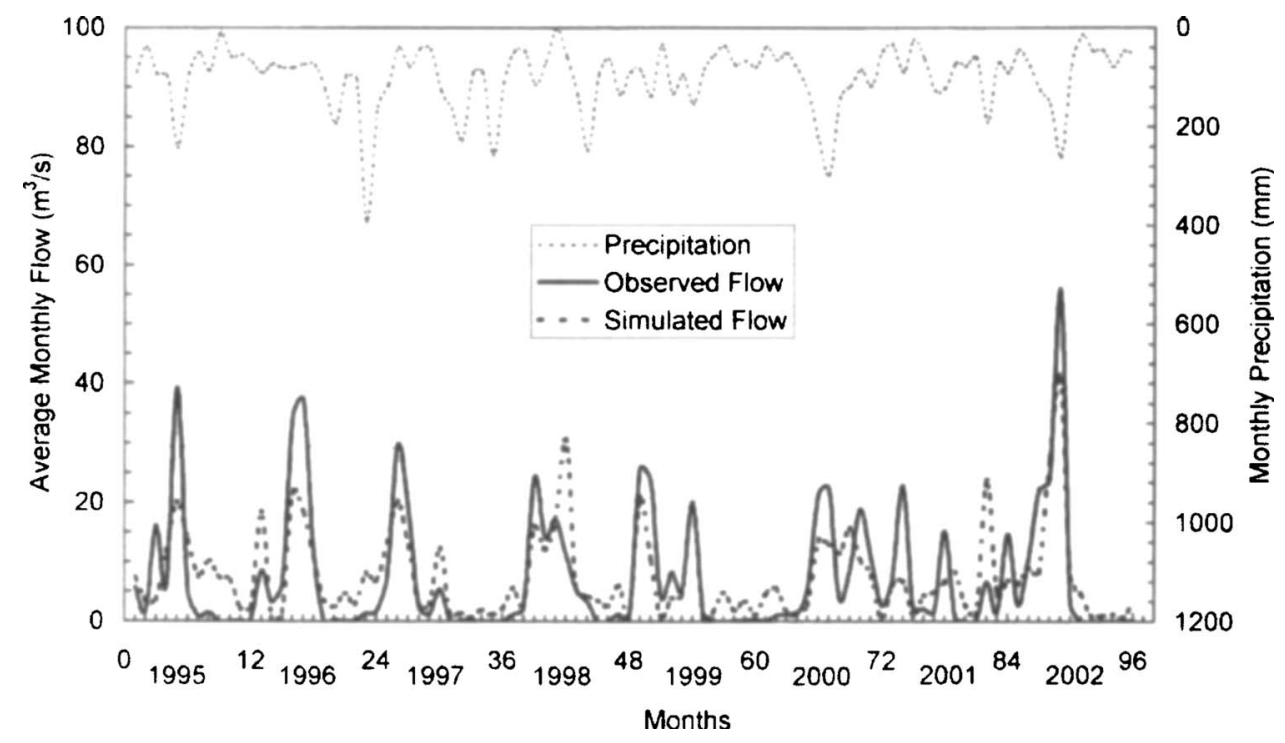

Fig. 2. Observed and SWAT-simulated monthly flows and precipitation on Little Wabash River at Effingham

sible COD and NCS for the individual years as well as cumulatively for the calibration years (1995-1999) and, therefore, the same values were used to simulate the validation period (20002002). During the validation period, COD and NSC values for the individual years were good for two of the years (2000: 0.50, 0.49; and 2002: 0.88, 0.84, respectively) and poor for 2001 (0.05 and -0.27 , respectively), a relatively dry year (Fig. 2). Poor performance of smaller (less intense) storms is a weakness of other physically based models, such as CASC2D, as well (Senarath et al. 2000). For the entire calibration and validation period (1995-2002), the cumulative COD and NSC improved to 0.61 and 0.60 , respectively. These statistics show that SWAT performed satisfactorily in predicting average monthly discharges or runoff volumes. However, it underpredicted most of the peak flows (Fig. 2), e.g., approximately 50\% in 1995 and 25\% in 2002.

(a)

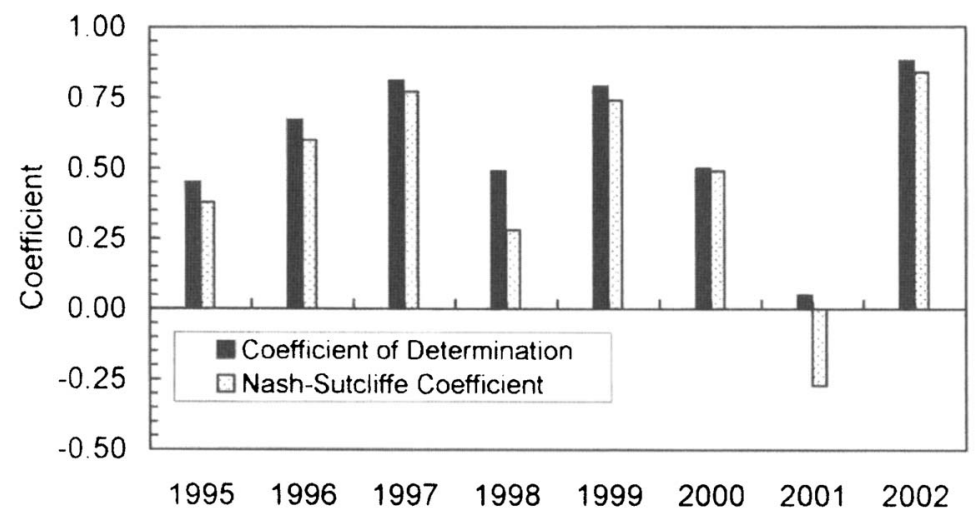

(b)

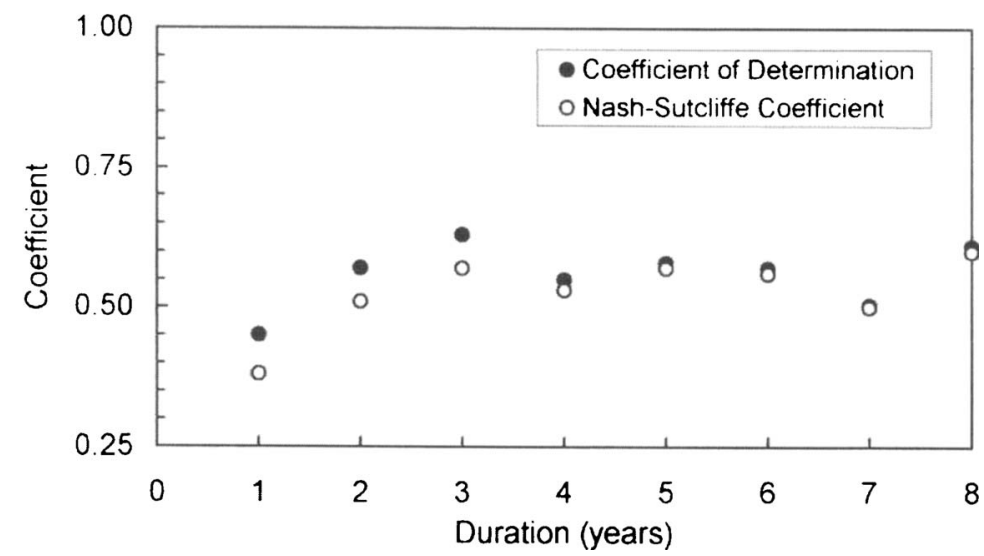

Fig. 3. Comparative parameters for SWAT simulated and observed monthly flows on Little Wabash River at Effingham: (a) individual years; (b) cumulative years 


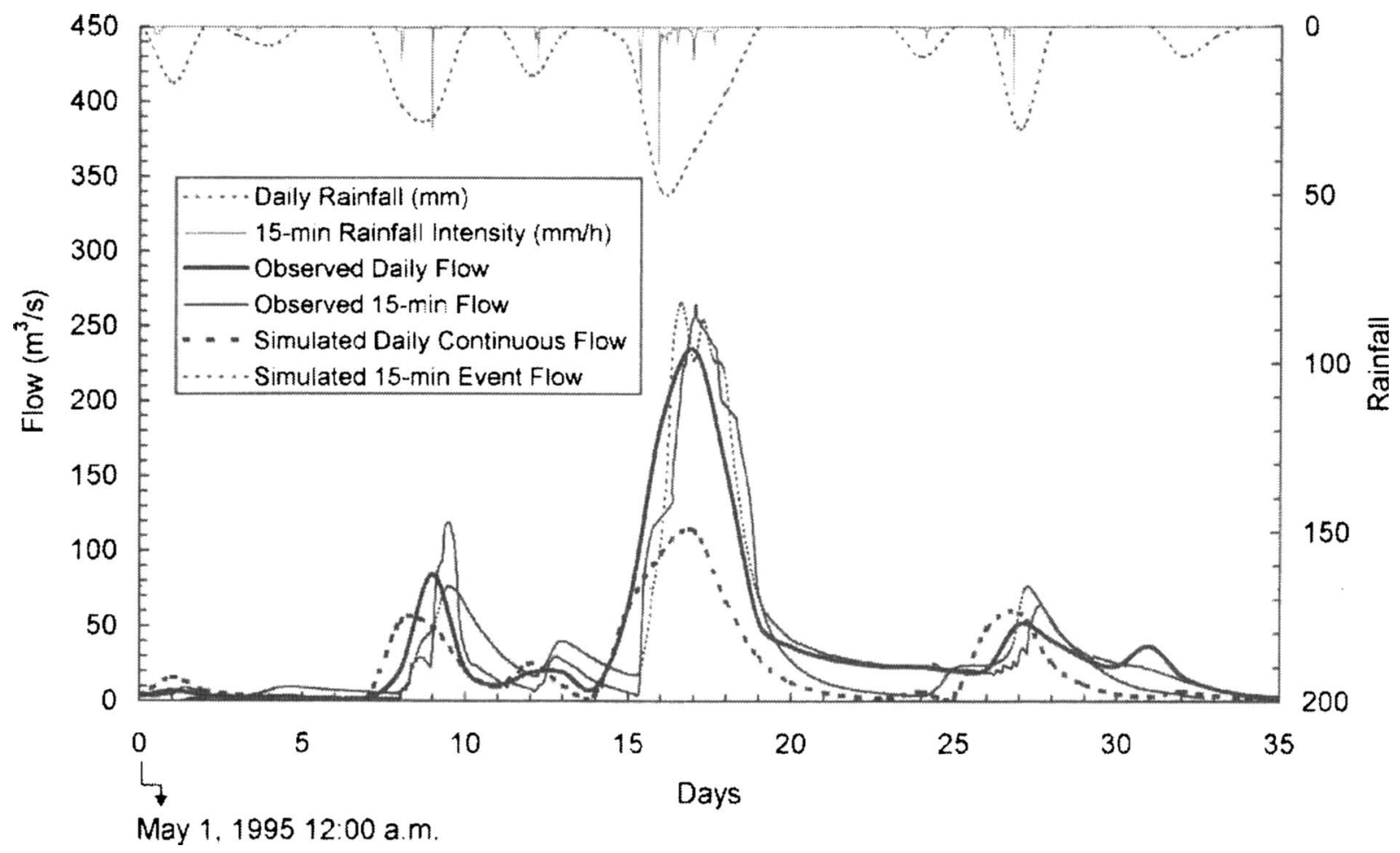

Fig. 4. Observed and simulated daily (SWAT) and 15-min event (DWSM) flows on Little Wabash River at Effingham during May 1-June 5, 1995 storms

Therefore, SWAT is a promising long-term continuous simulation model, which needs enhancements in storm event simulations for improving its high and peak flow predictions.

\section{Application of DWSM Storm-Event Hydrologic Model}

Each of the 88 subwatersheds of the Little Wabash River watershed, used in SWAT simulations, were further subdivided into two overland planes and one channel segment—totaling 176 overland planes and 88 channel segments. Areas, lengths, widths, and representative slopes of the overland planes, and channel lengths, slopes, widths, and depths were obtained from the SWAT data derived from BASINS GIS. Channel widths and depths given by these GIS data were used to develop relationships of wetted perimeters versus cross-sectional areas [factors $a$ and $b$ in Eq. (17)]. Fifteen-minute precipitation data at Effingham and Mason, the two closest rain gages to the watershed above Effingham $\left(620 \mathrm{~km}^{2}\right)$, were retrieved from the NCDC. Fifteen-min flow data at the stream gage at Effingham were obtained from the USGS.

First, a relatively intense mid-May 1995 storm was used to run and test the DWSM storm-event hydrology model. Values for the three parameters: (1) SCS runoff curve number CN; (2) effective lateral saturated hydraulic conductivity ELSHC; and (3) Manning's roughness coefficients $n$ for the overland planes and Manning's roughness coefficients $n$ for the channel segments-were taken from SWAT data. An overland plane may have several SWAT's HRUs. Therefore, area-based weighted averages were used. The ELSHC values were chosen from saturated hydraulic conductivity $K_{\text {sat }}\left(\mathrm{SOL} \_\mathrm{K}\right)$ values given in the SWAT menu from the literature. These SWAT values were sufficient for ELSHC due to Little Wabash River watershed characteristics generating mostly surface runoff.
Fig. 4 shows comparisons of observed and simulated hydrographs along with daily of rainfall and 15-min rainfall intensity data from May 1 to June 5, 1995 (35 days). In addition to the major storm event during Days 15-20, as shown in Fig. 4, there were smaller events before and after, which were also simulated. Fig. 4 shows comparisons of observed daily flows with SWAT daily flow simulations on the Little Wabash River at Effingham in addition to the comparisons of observed 15-min flows with 15min DWSM storm event flow simulations. Table 1 gives the simulated and observed peak flows, time to peak flows, runoff volumes, and percent differences (errors) of the respective observed and simulated values. Positive peak-flow and runoffvolume errors indicate overpredictions and negative underpredictions. Positive time to peaks errors indicate delayed simulated peak arrivals and negative advanced.

As shown in Fig. 4 and Table 1, the storm event DWSM predicted the peak flow and runoff volume for the simulation period better than the continuous SWAT with its daily time steps. The storm event model results are more detailed than the continuous daily results. It shows the precise time of arrival of the peak flow-15 min resolution in this case. In this application (Fig. 4), the storm event simulations predicted the intense-storm high flows (Days 15-20), much better than the daily continuous simulations. The storm event simulated peak flow of $266 \mathrm{~m}^{3} / \mathrm{s}$ has a deviation of $1 \%$ from its observed value $\left(264 \mathrm{~m}^{3} / \mathrm{s}\right)$. The simulated daily peak flow from the continuous model $\left(114 \mathrm{~m}^{3} / \mathrm{s}\right)$ is $51 \%$ underpredicted from the observed daily peak flow of $234 \mathrm{~m}^{3} / \mathrm{s}$, which is actually $57 \%$ less than the 15 -min observed peak flow of $264 \mathrm{~m}^{3} / \mathrm{s}$, a more realistic peak flow to be concerned with for flood warning, protection, or prevention.

Recalibration of the three parameters for the storm event DWSM was not necessary. Calibration or estimation of these pa- 
Table 1. Comparisons of Observed and Simulated SWAT Daily Continuous and DWSM 15-Min Event Peak Flows, Time to Peaks, and Runoff Volumes on Little Wabash River at Effingham

\begin{tabular}{|c|c|c|c|c|c|c|c|}
\hline \multirow[b]{2}{*}{ Period } & \multirow[b]{2}{*}{$\begin{array}{l}\text { Parameter } \\
\text { (unit) }\end{array}$} & \multicolumn{3}{|c|}{ SWAT daily continuous simulation } & \multicolumn{3}{|c|}{ DWSM 15-min event simulation } \\
\hline & & Simulated & Observed & $\begin{array}{c}\text { Percent } \\
\text { error } \\
(\%)\end{array}$ & Simulated & Observed & $\begin{array}{c}\text { Percent } \\
\text { error } \\
(\%)\end{array}$ \\
\hline \multirow[t]{3}{*}{ May 1-June 5, 1995} & Peak flow $\left(\mathrm{m}^{3} / \mathrm{s}\right)$ & 114 & 234 & -51 & 266 & 264 & 1 \\
\hline & Time to peak flow (days) & 17 & 17 & 0 & 17 & 17 & 0 \\
\hline & Runoff volume (ha m) & 6,719 & 11,140 & -40 & 10,393 & 10,990 & -5 \\
\hline \multirow[t]{3}{*}{ February 27-March 14, 1995} & Peak flow $\left(\mathrm{m}^{3} / \mathrm{s}\right)$ & 90 & 207 & -57 & 216 & 306 & -29 \\
\hline & Time to peak flow (days) & 8 & 9 & -11 & 8 & 9 & -11 \\
\hline & Runoff volume (ha m) & 1,697 & 4,105 & -59 & 3,225 & 4,087 & -21 \\
\hline \multirow[t]{3}{*}{ May $1-11,2002$} & Peak flow $\left(\mathrm{m}^{3} / \mathrm{s}\right)$ & 286 & 271 & 6 & 421 & 362 & 16 \\
\hline & Time to peak flow (days) & 7 & 6 & 17 & 6 & 6 & 0 \\
\hline & Runoff volume (ha m) & 6,150 & 7,926 & -22 & 6,438 & 7,227 & -11 \\
\hline
\end{tabular}

rameters in SWAT was sufficient. Therefore, these parameters are interchangeable and the models are compatible and complementary, which is unique. As a result, the DWSM storm event runs presented here are all validation runs.

Using the same parameter values, the storm event model DWSM was run for two other storm periods: February 27-March 14, 1995 and May 1-11, 2002. Similar comparisons are presented in Figs. 5 and 6, and Table 1. Performances of the models during these two storm periods are similar to the May-June 1995 storm, as discussed above, except for SWAT predicting daily flows exceptionally well during the May 2002 storm period (Fig. 6).

A shown in Figs. 4-6 and Table 1 from the three storm simulations, DWSM's 15-min peak flow errors were $1,-29$, and $16 \%$; volume errors were $-5,-21$, and $-11 \%$ (all underpredictions); and time to peak flow errors were $0,-11$ (advanced), and $0 \%$, respectively. Similarly, SWAT's daily flow prediction errors were: peak $-51,-57$, and $6 \%$; volume $-40,-59$, and $-22 \%$ (all underpredictions), and time to peak $0,-11$, and $17 \%$, respectively.

\section{Conclusions}

Mathematical formulations of long-term continuous hydrologic simulations in SWAT and storm event hydrologic simulations in DWSM are complementary and compatible for combining into a more comprehensive (combined storm event and continuous) and efficient watershed simulation model.

DWSM's watershed characteristics data can be derived from SWAT data and its three physically based hydrologic parameters

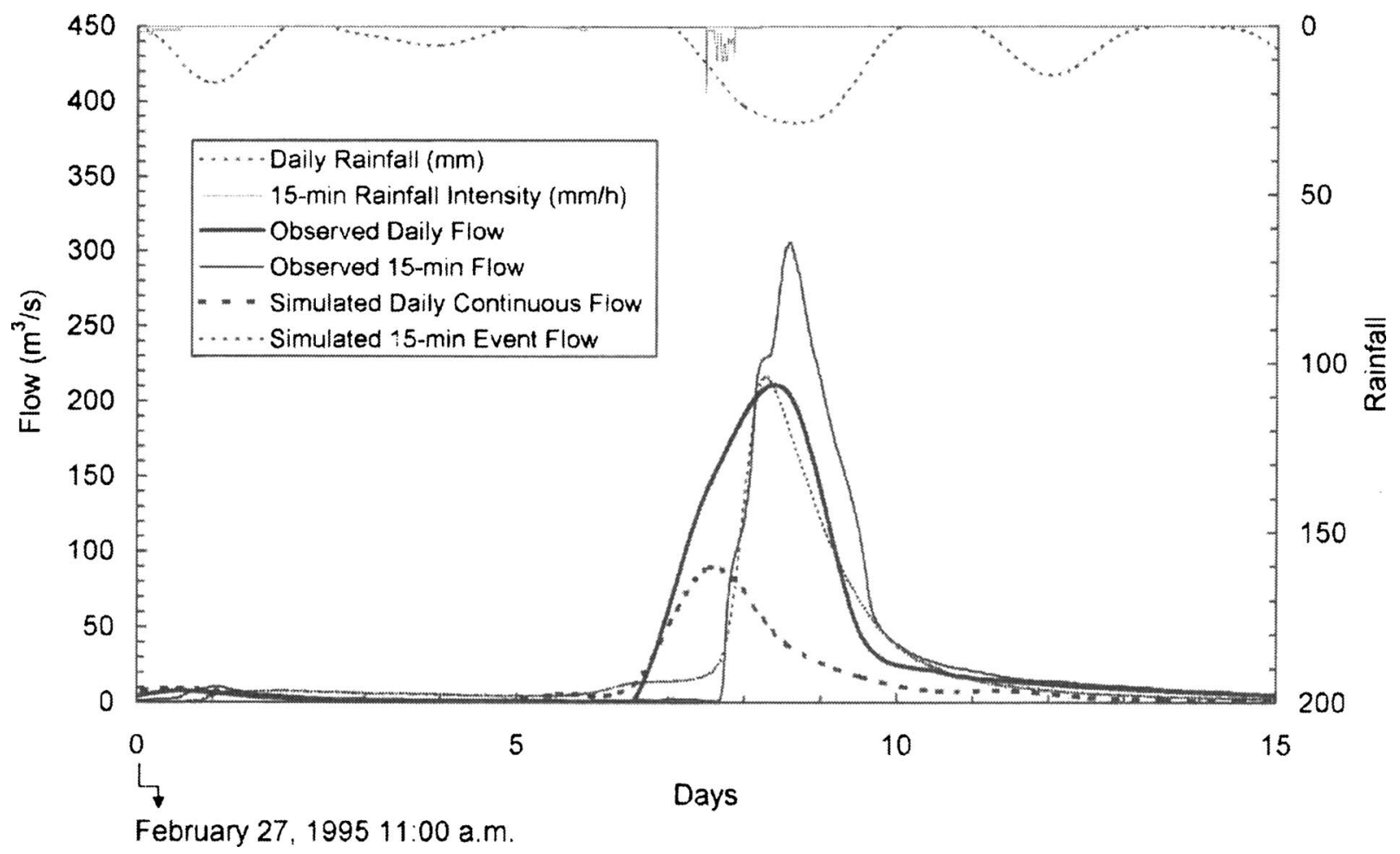

Fig. 5. Observed and simulated daily (SWAT) and 15-min event (DWSM) flows on Little Wabash River at Effingham during February 27-March 14, 1995 storms 


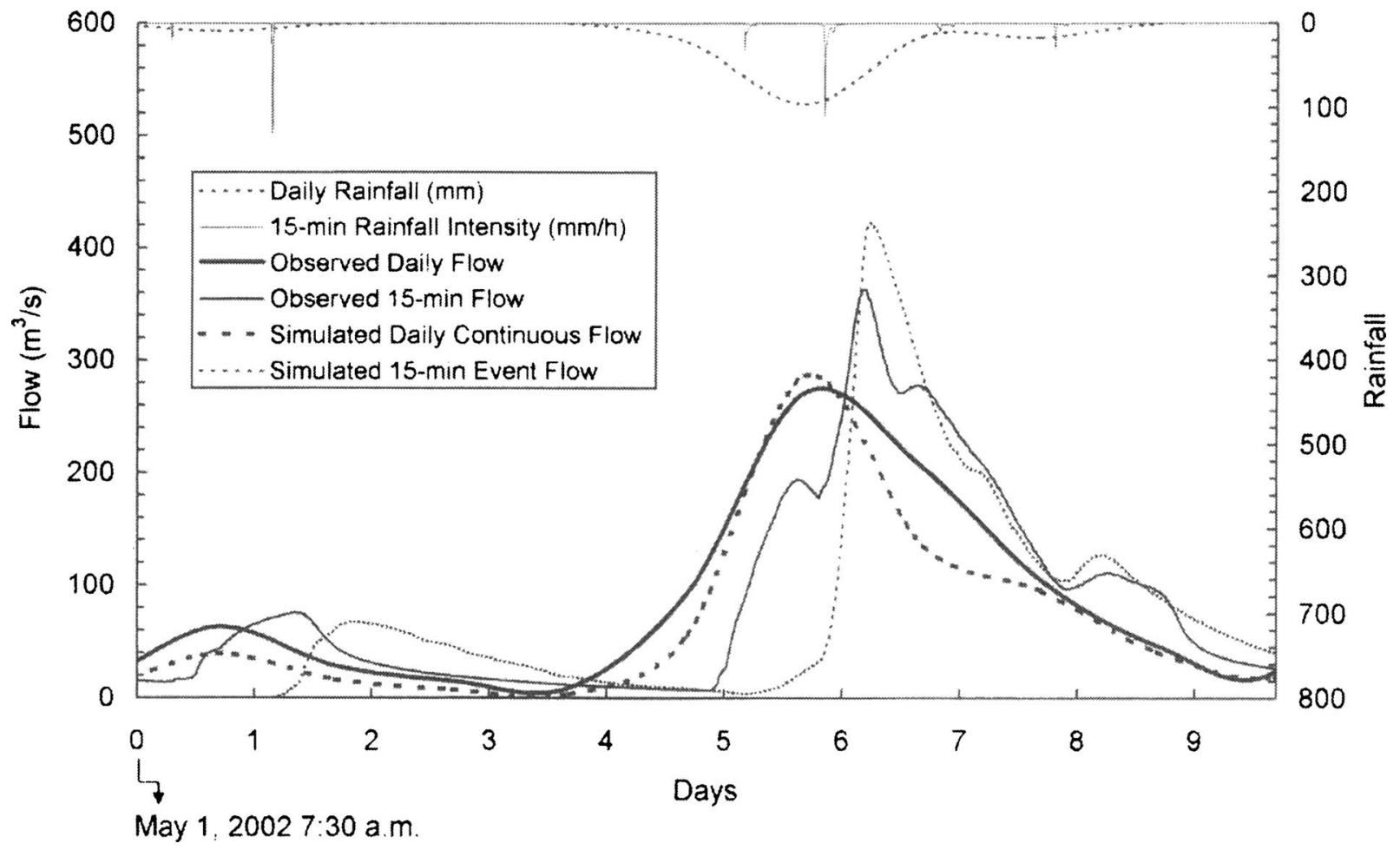

Fig. 6. Observed and simulated daily (SWAT) and 15-min event (DWSM) flows on Little Wabash River at Effingham during May 1-11, 2002 storms

can be taken from their estimations or calibrations in SWAT. Therefore, the common data and parameters of these two models are interchangeable, not requiring recalibration once calibrated (or estimated) in one of the models.

The long-term continuous hydrologic simulations of SWAT performed satisfactorily in predicting monthly average flows on the Little Wabash River at Effingham, Ill. Comparisons of monthly simulated and observed flows resulted in coefficients of determination and Nash-Sutcliffe coefficients for individual years and cumulatively for the calibration period (1995-1999) and for the entire simulation period (1995-2002) mostly above or near 0.50 with an exception of 0.05 and -0.27 , respectively, in 2001 , a dry year when physically based models normally perform poorly.

SWAT underpredicted most of the monthly peak flows during the 8-year simulations of the Little Wabash River watershed at Effingham, some on the order of $50 \%$. Therefore, SWAT needs enhancements in storm event simulations for improving its high and peak flow predictions.

Using values of three parameters (curve numbers, saturated hydraulic conductivities, and Manning's roughness coefficients) from SWAT, the DWSM storm event hydrologic model performed satisfactorily on three storms in May 1995, March 1995, and May 2002 resulting in comparable flow hydrographs with the observed; peak flow errors of $1,-29$, and $16 \%$; volume errors $-5,-21$, and $-11 \%$; and time to peak errors $0,-11$, and $0 \%$, respectively.

SWAT's daily flow simulations during the above three storms were found mixed. It underpredicted daily peak flows in two of the storms by 51 and $57 \%$, but performed well for one of the storms, where daily peak flow was overpredicted by $6 \%$.

Comparisons of DWSM's 15-min flow hydrographs with SWAT's daily flow hydrograph along with the 15-min and daily observed hydrographs during the above three storms confirmed more accurate predictions of high and peak flows by DWSM than SWAT. DWSM's peak flow arrival time was more precise than SWAT as expected.

DWSM's robust routing scheme using analytical and approximate shock-fitting solutions of the kinematic wave equations was responsible for the better predictions, addition of which along with its unique combination with the popular runoff curve number method for rainfall excess computation to SWAT would be a significant enhancement.

Uncertainties, resulting from deterministic modeling of natural processes and measurements or observations of data used in modeling, must be considered when using model results in management decisions and policy making, which are subjects of future research.

\section{Acknowledgments}

This paper is based on research supported by the Midwest Technology Assistance Cent (MTAC) and the Illinois State Water Survey (ISWS). Any opinions, findings, and conclusions recommendations expressed in this paper are those of the authors and do not necessarily reflect the views of ASCE, MTAC, or ISWS. Mention of products or commercial services does not reflect endorsement by the authors, ASCE, MTAC, or ISWS.

\section{References}

Arnold, J. G., Srinivasan, R., Muttiah, R. S., and Williams, J. R. (1998). "Large area hydrologic modeling and assessment. I: Model development." J. Am. Water Resour. Assoc., 34(1), 73-89. 
Barker, B., Carlisle, J. B., and Nyberg, R. (1967). Little Wabash River Basin study: A comprehensive plan for water resource development, Illinois Development of Public Works and Buildings, Division of Waterways, Springfield, Ill.

Beasley, D. B., Huggins, L. F., and Monke, E. J. (1980). "ANSWERS: A model for watershed planning." Trans. ASAE, 23(4), 938-944.

Bicknell, B. R., Imhoff, J. C., Kittle, Jr., J. L., Donigian, Jr., A. S., and Johanson, R. C. (1993). "Hydrologic Simulation ProgramFORTRAN (HSPF): User's manual for Release 10." Rep. No. EPA/ 600/R-93/174. U.S. EPA Environmental Research Lab, Athens, Ga.

Borah, D. K. (1989). "Runoff simulation model for small watersheds." Trans. ASAE, 32(3), 881-886.

Borah, D. K., and Bera, M. (2003). "Watershed-scale hydrologic and nonpoint-source pollution models: Review of mathematical Bases." Trans. ASAE, 46(6), 1553-1566.

Borah, D. K., and Bera, M. (2004). "Watershed scale hydrologic and nonpoint source pollution models: Review of applications." Trans. ASAE, 47(3), 789-803.

Borah, D. K., Bera, M., and Xia, R. (2004). "Storm event flow and sediment simulations in agricultural watersheds using DWSM." Trans. ASAE, 47(5), 1539-1559.

Borah, D. K., Krug, E. C., Bera, M., and Liang, X.-Z. (2006a). "Watershed modeling to evaluate water quality at intakes of small drinking water systems." Draft Contract Rep. Submitted to Midwest Technology Assistance Center, Illinois State Water Survey, Champaign, Ill.

Borah, D. K., Prasad, S. N., and Alonso, C. V. (1980). "Kinematic wave routing incorporating shock fitting." Water Resour. Res., 16(3), 529-541.

Borah, D. K., Xia, R., and Bera, M. (2002). "Chapter 5: DWSMA dynamic watershed simulation model." Mathematical models of small watershed hydrology and applications, V. P. Singh and D. K. Frevert, eds., Water Resources Publications, Highlands Ranch, Colo., 113-166.

Borah, D. K., Yagow, G., Saleh, A., Barns, P. L., Rosenthal, W., Krug, E. C., and Hauck, L. M. (2006b). "Sediment and nutrient modeling for TMDL development and implementation." Trans. ASABE, 49(4), 967-986.

Bouraoui, F., Braud, I., and Dillaha, T. A. (2002). "Chapter 22: ANSWERS: A nonpoint source pollution model for water, sediment and nutrient losses." Mathematical models of small watershed hydrology and applications, V. P. Singh and D. K. Frevert, eds., Water Resources Publications, Highlands Ranch, Colo., 833-882.

DiLuzio, M., Srinivasan, R., and Arnold, J. G. (2002). "Integration of watershed tools and SWAT model into BASINS." J. Am. Water Resour. Assoc., 38(4), 1127-1141.

Goolsby, D. A., Battaglin, W. A., Lawrence, G. B., Artz, R. S., Aulenbach, B. T., Hooper, R. P., Keeney, D. R., and Stensland, G. J. (1999). "Flux and sources of nutrients in the Mississippi-Atchafalaya River Basin." Task Group 3 Rep. Gulf of Mexico Hypoxia Assessment, White House Committee on Environment and Natural Resources, Washington, D.C.

Hargreaves, G. H., and Samani, Z. A. (1985). "Reference crop evapotranspiration from temperature." Appl. Eng. Agric., 1, 96-99.

Illinois Department of Natural Resources (IDNR). (2001). Critical Trends in Illinois Ecosystems, Annual Report, Critical Trend Assessment Program, Springfield, Ill.

Illinois Environmental Protection Agency (IEPA). (2004). "Illinois 2004 Section 303(d) list." IEPA/BOW/04-005, Bureau of Water, Springfield, Ill., 〈http://www.epa.state.il.us/water/tmdl/303d-list.html), (December 20, 2005).

Leavesley, G. H., Lichty, R. W., Troutman, B. M., and Saindon, L. G. (1983). "Precipitation-runoff modeling system-User's manual." U.S. Geological Survey Water Resources Investigative Rep. No. 83-4238, U.S. Geological Survey, Washington, D.C.

Lighthill, M. J., and Whitham, C. B. (1955). "On kinematic waves. I: Flood movement in long rivers." Proc. R. Soc. London, Ser. A, 229, 281-316.
Linsley, R. K., Kohler, M. A., and Paulhus, J. L. H. (1958). Hydrology for engineers, McGraw-Hill, New York.

Monteith, J. L. (1965). "Climate and the efficiency of crop production in Britain." Philos. Trans. R. Soc. London, Ser. B, 281, 277-329.

Nash, J. E., and Sutcliffe, J. V. (1970). "River flow forecasting through conceptual models. I: A discussion of principles." J. Hydrol., 10(3), 282-290.

National Climate Data Center (NCDC). (2005). "NOAA satellite and information service: National environmental satellite, data, and information service (NESDIS)." U.S. Dept. of Commerce, Washington, D.C. 〈http://www.ncdc.noaa.gov/oa/ncdc.html〉, (December 1, 2005).

Neitsch, S. L., Arnold, J. G., Kiniry, J. R., Srinivasan, R., and Williams, J. R. (2002). "Soil and water assessment tool user's manual Version 2000." GSWRL Rep. No. 02-02, BRC Rep. No. 02-06, TR-192, Texas Water Resources Institute, College Station, Tex.

Ogden, F. L., and Julien, P. Y. (2002). "Chapter 4: CASC2D-A twodimensional, physically-based, hortonian hydrologic model." Mathematical models of small watershed hydrology and applications, V. P. Singh and D. K. Frevert, eds., Water Resources Publications, Highlands Ranch, Colo., 69-112.

Perrin, C., Michel, C., and Andréassian, V. (2001). "Does a large number parameters enhance model performance? Comparative assessment of common catchment model structures on 429 catchments." J. Hydrol., 242, 275-301.

Priestley, C. H. B., and Taylor, R. J. (1972). "On the assessment of surface heat flux and evaporation using large-scale parameters." Mon. Weather Rev., 100, 81-92.

Refsgaard, J. C., and Storm, B. (1995). "Chapter 23: MIKE SHE." Computer models of watershed hydrology, V. P. Singh, ed., Water Resources Publications, Highlands Ranch, Colo., 809-846.

Saleh, A., and Du, B. (2004). "Evaluation of SWAT and HSPF within BASINS program for the Upper North Bosque River watershed in Central Texas." Trans. ASAE, 47(4), 1039-1049.

Senarath, S. U. S., Ogden, F. L., Downer, C. W., and Sharif, H. O. (2000). "On the calibration and verification of two-dimensional, distributed, Hortonian, continuous watershed models." Water Resour. Res., 36(6), 1495-1510.

Singh, V. P., ed. (1995). Computer models of watershed hydrology, Water Resources Publications, Highlands Ranch, Colo.

Singh, V. P., and Frevert, D. K., eds. (2002a). Mathematical models of large watershed hydrology, Water Resources Publications, Highlands Ranch, Colo.

Singh, V. P., and Frevert, D. K., eds. (2002b). Mathematical models of small watershed hydrology and applications, Water Resources Publications, Highlands Ranch, Colo.

Singh, V. P., and Frevert, D. K., eds. (2006). Watershed models, CRC Taylor and Francis, Boca Raton, Fla.

Sloan, P. G., Moore, I. D., Coltharp, G. B., and Eigel, J. D. (1983). "Modeling surface and subsurface stormflow on steeply-sloping forested watersheds." Water Resources Institute Rep. No. 142, Univ. of Kentucky, Lexington, Ky.

State Water Survey Staff. (1948). "Water resources of Southern Illinois." Rep. to Joint Committee on Southern Illinois, Univ. of Illinois, Urbana-Champaign, Ill.

U.S. Army Corps of Engineers. (1979) "Final environmental impact statement: Louisville Lake, Little Wabash River Basin, Illinois.” Louisville District, Louisville, Ky.

USDA Soil Conservation Service (SCS). (1972). "Section 4: Hydrology." National engineering handbook, Washington, D.C.

USDA Soil Conservation Service (SCS). (1986). "Urban hydrology for small watersheds." Technical Release 55, Washington, D.C.

USEPA. (2001). "Better assessment science integrating point and nonpoint sources: BASINS Version 3.0 user's manual." EPA-823-B-01001, Office of Water, Washington, D.C. 〈http://www.epa.gov/ waterscience/basins/b3webdwn.htm $\rangle$, (August 6, 2006).

USEPA. (2007). "Better assessment science integrating point and nonpoint sources." Washington, D.C, 〈http://www.epa.gov/OST/ BASINS $\rangle$, (July 30, 2007). 
USGS. (2005). "USGS suface-water data for Illinois." Dept. of the Interior, Reston, Va., 〈http://waterdata.usgs.gov/il/nwis/sw〉, (December 20, 2005).

USGS, and Illinois Environmental Protection Agency (IEPA). (2003). "Source water assessment program for Illinois." 〈http:// il.water.usgs.gov/factsheets/ $\rangle$, (July 13, 2004).

Van Liew, M. W., Arnold, J. G., and Garbrecht, J. D. (2003). "Hydrologic simulation on agricultural watersheds: Choosing between two models." Trans. ASAE, 46(6), 1539-1551.

Williams, J. R. (1969). "Flood routing with variable travel time or vari- able storage coefficients." Trans. ASAE, 12(1), 100-103.

Woolhiser, D. A., Smith, R. E., and Goodrich, D. C. (1990). "KINEROS, A kinematic runoff and erosion model: Documentation and user manual." ARS-77, U.S. Department of Agriculture, Agricultural Research Service, Fort Collins, Colo.

Young, R. A., Onstad, C. A., Bosch, D. D., and Anderson, W. P. (1987). "AGNPS, Agricultural nonpoint-source pollution model: A watershed analytical tool." Conservation Research Rep. No. 35, U.S. Department of Agriculture, Washington, D.C. 